\title{
Epigenetic Axis of Long Noncoding RNA HCG18 and miR-146a-5p Regulates Sepsis-Associated Myocardial Injury
}

\section{Hua Wang}

Beijing Chao-Yang Hospital: Beijing Chaoyang Hospital

Wen-Shu Zhao

Beijing Chaoyang Hospital

lin xu ( $\square$ lxdrqw09_dr@aol.com )

Beijing Chaoyang Hospital https://orcid.org/0000-0002-9096-5062

\section{Keywords:}

Posted Date: April 5th, 2021

DOl: https://doi.org/10.21203/rs.3.rs-378461/v1

License: (c) (i) This work is licensed under a Creative Commons Attribution 4.0 International License.

Read Full License 


\section{Abstract}

The authors have requested that this preprint be removed from Research Square. 